\title{
ENVIRONMENTAL IMPACT ASSESSMENT OF PETROL AND GAS FILLING STATIONS ON AIR QUALITY IN UMUAHIA, NIGERIA
}

\author{
OKONKWO UGOCHUKWU C., ORJI IJIOMA N. AND ONWUAMAEZE IKECHUKWU
}

\begin{abstract}
This study investigated pollutants emissions from filling stations and their impact on the air quality. Gas monitors were employed to identify the different pollutants present in the ambient air of the study areas. The results showed that the most prominent pollutants present in the ambient air are the volatile organic compounds followed by methane, then carbon monoxide. Measurements were taken at the controls at distances between 20 to $200 \mathrm{~m}$. The pollutants concentration recorded at the study areas showed that the level of pollutants exceeded the FEPA air quality guidelines. There are few exceptions in pollutants like the particulate matter which was found to be at concentrations within the FEPA limits. Regression analysis of the pollutants at the controls showed that only the volatile organic compounds and methane are the only significant pollutants present in the ambient air primarily because of the presence of the filling stations. These two pollutants showed a strong negative correlation with distance from the study area. While the regression curve for the volatile organic compounds (VOCs) shows a nearly perfect curve with exponential functions as its regression equations, that of methane is linear. Specifically, both VOCs and methane have a correlation coefficient $(R)$ that is above 0.9 for the study areas. Hence a conclusion was drawn from the findings that the primary pollutant to consider when building filling station are the VOCs and methane and that the minimum safe distance to site a filling station is a distance of $80 \mathrm{~m}$ away from residential areas.
\end{abstract}

KEYWORDS: Filling Station, Pollutants, Air Quality, VOCs, Methane

\section{INTRODUCTION}

With the advent of industrial revolution came the demand for a better source of energy which in previous times were being provided by human and animal muscle and later by the combustion of solid fuels such as wood, peat and coal. One problem associated with the use of these solid fuels is the amount of effort geared towards harnessing the energy. Liquid petroleum on the other hand proved to be a cheaper source of energy. Oil was a much more concentrated and flexible source of energy than anything that was previously available. At the beginning of the $20^{\text {th }}$ century the industrial revolution has progressed to the extent that the use of refined oil primarily for illumination ceased to be of primary importance. The oil industry became a major supplier of energy largely because of the advent of the automobile industry. Although oil constitutes a major petrochemical feedstock, its primary importance can be seen in the fact that it is an energy source on which the world economy depends [1]. The production and consumption of oil is vital to international relations and has frequently been a decisive factor in the determination of foreign policy

From the above fact, one can see how oil has played a major role in the advancement of technology in our time. But just like every other

Okonkwo Ugochukwu C., Department of Mechanical Engineering, Nnamdi Azikiwe University, Awka, Nigeria.

Orji Ijioma N., Department of Mechanical Engineering, Nnamdi Azikiwe University, Awka, Nigeria.

Onwuamaeze Ikechukwu, Department of Mechanical Engineering, Petroleum Training Institute, Effurum, Warri. Nigeria. 
technology, oil discovery has come with some of its disadvantages. One of such disadvantage is its negative impact on the earth's biosphere releasing pollutants and greenhouse gases into the environment and damaging ecosystem through events such as oil spillage [2]. This situation has resulted to developed countries beginning to emphasize on a cleaner and a more environmentally friendly energy source. Nigeria with a large reserve of crude and natural gas has its energy needs met by these fossil fuels. The Nigerian economy is largely dependent on the exportation of crude. The recent population explosion in Nigeria triggered an increase in the demand for petroleum products. Here, more filling stations are being built in other to meet with the increasing demand for fuel. The situation is such that it is becoming very common to see filling stations located very close to residential areas. The disadvantage seen from this development is the increased pollution of the air caused by the continued emission of toxic gases into the air. These emissions originate from the following sources viz gasoline delivery to the stations, tank breathing which occurs due to temperature and pressure changes, during vehicle refueling, emissions from loosely closed tanks and mishandling of the petroleum leading to spillage [3]. There is also the emission of combustion products from vehicle engines present in the station.

These gases that are being emitted into the atmosphere are hazardous to human health. One of the most prominent of these gases is the volatile organic compounds (VOCs) which are reported by the world health organization as the major cause of cancer in humans [4]. Numerous studies found that all types of air pollutants at high concentration can affect the airways, nevertheless, similar effects are also observed with long term exposure to lower pollutants concentrations. Symptoms such as nose and throat irritation, followed by bronchro constriction and dyspnosa especially in asthmatic individual are usually experienced after exposure to increased level of sulphur dioxide and nitrogen and certain heavy metals such as arsenic or vanadium $[5,6]$. In addition particulate matter that penetrates the alveolar epithelium and initiate lung inflammation [7] in patients with lung lesions or lung diseases. Moreover, air pollutants such as nitrogen oxide increase the susceptibility to respiratory infections. The aim of this study is to investigate the pollutants that are released from the petrol stations and its negative impact on the air quality afterwhich solutions necessary in arresting this ugly trend in other to protect the life of the general populace from the harmful effect of these pollutants will be proffered.

\section{RESEARCH METHODOLOGY}

In this study, three different filling stations were studied in Umuahia. These filling stations are located at different parts of Umuahia namely; Mission Hill Umuahia $\left(\cup_{1}\right)$, Hospital road (close to FMC) $\left(U_{2}\right)$, and Aba road $\left(U_{3}\right)$. Umuahia is the capital of Abia state and is located along the rail line that lies between Port Harcourt to Umuahia south and Enugu city to its north. Its coordinates is $5^{0} 32^{\prime} \mathrm{N} 7^{0}$ [8]. Equipment used in the air quality monitoring and measurement include an AEROCET 531 particle mass monitor, a Garmin U10 map GPS equipped with a compass and an AEROQUAL Environmental gas monitor (300 series). The Aerocet 531 particle gas monitor was used in measuring the concentrations of the particulate matter. The garmin U10 map GPS measures the wind direction while the AEROQUAL environmental gas monitor measures the concentrations of products of combustion and the volatile organic compounds.

Each of the filling stations was visited and the ambient air quality was measured at different point of the filling station namely; the front of the stations, the dispenser area, the generator room, and the controls. The controls are points between $20 \mathrm{~m}$ to $200 \mathrm{~m}$ away from each filling station. The aim of the control is to ascertain how far the pollutants travel and to determine which of the pollutants is directly present in the atmosphere as a result of the activities in the study areas. The measurements were carried out twice in each sampling point and the average used for analysis. Nine different air pollutants were measured and their data collected from each filling station. These pollutants include the suspended particulate matter $\left(\mathrm{PM}_{1}, \mathrm{PM}_{2.5}\right.$, and TSP), carbon monoxide, Nitrogen (iv) oxide, sulphur (iv) oxide, hydrogen sulphide, methane, and volatile organic compounds.

The data collected from each filling station were compared to the FEPA air quality Standard to determine whether the pollutants concentrations are within the acceptable limits.The data collected at the control were treated with regression and correlation analysis to determine the relationships that exist between the pollutant concentration and the distance from 
the filling stations. Correlation coefficient was calculated in other to determine the strength of the relation that exists between distance from the filling stations and concentration of the pollutants.

\section{RESULTS AND DISCUSSION}

The results of the air quality measurement at the study areas are summarized in table 1.

Table 1: Average concentration of pollutants at the study stations

\begin{tabular}{|l|l|l|l|}
\hline Pollutants & $\mathrm{U}_{1} \mathrm{mg} / \mathrm{m}^{3}$ & $\mathrm{U}_{2} \mathrm{mg} / \mathrm{m}^{3}$ & $\mathrm{U}_{3} \mathrm{mg} / \mathrm{m}^{3}$ \\
\hline $\mathrm{PM}_{1}$ & 0.01 & 0.01 & 0.01 \\
\hline $\mathrm{PM}_{2.5}$ & 0.07 & 0.02 & 0.09 \\
\hline $\mathrm{TSP}$ & 0.36 & 0.03 & 0.25 \\
\hline $\mathrm{NO}_{2}$ & 0.60 & 0.20 & 0.15 \\
\hline $\mathrm{SO}_{2}$ & 0.18 & 0.13 & 0.23 \\
\hline $\mathrm{VOCs}$ & 152.12 & 89.65 & 56.72 \\
\hline $\mathrm{H}_{2} \mathrm{~S}$ & 0.03 & 0.07 & 0.10 \\
\hline $\mathrm{CO}$ & 6.48 & 6.72 & 3.24 \\
\hline $\mathrm{CH}$ & 6.51 & bdl & 7.74 \\
\hline
\end{tabular}

*bdl - below detection limit

Table 1 shows the average concentration of the pollutants at the study areas. Here the volatile organic compounds are seen to be the most prominent pollutants recorded. This because of the continuous emission of the fuel vapours into the ambient air as a result of mishandling of the fuel which may lead to spillage, the displacement of air carrying fuel from the tanks during vehicle refueling and the evaporation of fuels from loosely closed underground tanks. More VOCs were recorded at the dispensing areas and the reason is because evaporation of fuel occurs during the refueling of vehicles. There is a wide gap in the concentration of VOCs recorded at $U_{1}$ (i.e. $152.12 \mathrm{mg} / \mathrm{m}^{3}$ ) compared with that of $U_{2}$ and $U_{3}$ (89.65 and $56.72 \mathrm{mg} / \mathrm{m}^{3}$, respectively). This is because $U_{1}$ is a very busy station compared to $U_{2}$ and $U_{3}$ at the periods that the measurements were carried out and the direct consequence of this is that more of the pollutants will be released into the ambient air at $U_{1}$ when compared with the other two.Methane was also found to be in high concentration at $U_{1}$ and $U_{3}$ and this comes from leakages from the storage tanks for cooking gas and evaporation during the dispensing of the gas to buyers. No trace of methane was recorded at station $U_{2}$ because cooking gas was not sold in the area.

$\mathrm{CO}_{2}$ was found in high concentration in the stations especially at the generator room because of incomplete combustion of fuel in the vehicle and generator engines present in the station. Incomplete combustion occurs as a result of faulty engines or due to lack of oxygen necessary for complete combustion. $\mathrm{H}_{2} \mathrm{~S}, \mathrm{SO}_{2}$ and $\mathrm{NO}_{2}$ that were recorded in the ambient air of the stations are all products of the combustion of fossil fuel in the generator and vehicle engines present in the filling stations. $\mathrm{SO}_{2}$ is found when fuel containing sulphur is burnt while $\mathrm{NO}_{2}$ is released from the engines exhaust as a result of reaction with other gases present in the exhaust and in the atmosphere. Particulate matters are dust carried by the vehicles as they gain entrance in the filling stations. It was also recorded in the generator room at high concentration owing to the release of soot from the exhaust of the generators. It is believed that particulate matter from a nearby eagle cement factory contributed to the particulate matter in the ambient air. Different particulate matters were recorded and this include the $\mathrm{PM}_{1}, \mathrm{PM}_{2.5}$ and the total suspended particle (TSP) which is a combination of the other grades of particulate matter.

\section{Comparing the Pollutants Concentration in Study Areas to the FEPA Air Quality Guidelines}

The national agency responsible for setting and maintaining environmental standard in Nigeria has stated the air quality standards/guidelines. The table 2 shows the Federal Environmental Protection Agency (FEPA) standards for the different pollutants [9]. 
Table 2: FEPA air quality guidelines

\begin{tabular}{|l|l|l|}
\hline Pollutants & FEPA limits $\left(\mathrm{mg} / \mathrm{m}^{3}\right)$ & Time Limit (min) \\
\hline $\begin{array}{l}\text { Suspended particles } \\
\left(\mathrm{PM}_{1} \text { \& } \mathrm{PM}_{2.5}, \text { TSP }\right)\end{array}$ & 0.15 & 30 \\
\hline $\mathrm{NO}_{2}$ & 0.09 & 30 \\
\hline $\mathrm{SO}_{2}$ & 0.5 & 30 \\
\hline VOCs & 40 & 30 \\
\hline $\mathrm{H}_{2} \mathrm{~S}$ & 0.08 & 30 \\
\hline $\mathrm{CO}$ & 5.0 & 30 \\
\hline
\end{tabular}

Table 3: Comparison between the average concentration of pollutants and the FEPA air quality guidelines

\begin{tabular}{|l|l|l|l|}
\hline Pollutants & $\mathrm{U}_{1}$ & $\mathrm{U}_{2}$ & \multicolumn{1}{|c|}{$\mathrm{U}_{3}$} \\
\hline $\mathrm{PM}_{1}$ & $0.01<0.15$ & $0.01<0.15$ & $0.01<0.15$ \\
\hline $\mathrm{PM}_{2.5}$ & $0.07<0.15$ & $0.02<0.15$ & $0.09<0.15$ \\
\hline $\mathrm{TSP}$ & $0.36>0.15$ & $0.03<0.15$ & $0.25>0.15$ \\
\hline $\mathrm{NO}_{2}$ & $0.60>0.09$ & $0.20>0.09$ & $0.15>0.09$ \\
\hline $\mathrm{SO}_{2}$ & $0.18<0.5$ & $0.13<0.5$ & $0.23<0.5$ \\
\hline $\mathrm{VOCs}$ & $152.12>40$ & $89.65>40$ & $56.72>40$ \\
\hline $\mathrm{H}_{2} \mathrm{~S}$ & $0.03<0.08$ & $0.07<0.08$ & $0.10>0.08$ \\
\hline $\mathrm{CO}$ & $6.48>5.0$ & $6.72>5.0$ & $3.24<5.0$ \\
\hline
\end{tabular}

Table 3 summarizes the comparison between the average concentrations of pollutants at the study areas to the FEPA air quality guidelines. At $U_{1}$ $\mathrm{PM}_{1}, \mathrm{PM}_{2.5}, \mathrm{SO}_{2}$ and $\mathrm{H}_{2} \mathrm{~S}$ are found to be within the FEPA specified limits while TSP, $\mathrm{NO}_{2}$, VOCs and $\mathrm{CO}$ exceeded the FEPA limits. The situation at $\mathrm{U}_{2}$ shows that $\mathrm{PM}_{1}, \mathrm{PM}_{2.5}, \mathrm{TSP}, \mathrm{SO}_{2}$ and $\mathrm{H}_{2} \mathrm{~S}$ are within the FEPA limits while $\mathrm{NO}_{2}$, VOCs and $\mathrm{CO}$ exceeded the FEPA limits. At $\mathrm{U}_{3}, \mathrm{PM}_{1}, \mathrm{PM}_{2.5}$, $\mathrm{SO}_{2}$, and $\mathrm{CO}$ are within the FEPA limits while pollutant TSP, $\mathrm{NO}_{2}$, VOCs and $\mathrm{H}_{2} \mathrm{~S}$ all exceeded the FEPA limits. The situation in all the stations shows that the air quality is negatively affected as some of the pollutants recorded exceeded the FEPA exposure limits. This implies that the health of those in the station or within the surrounding of the stations is at risk owing to their exposure to polluted air. For example exposure to the VOCs is known to cause cancer in humans according to the world health organization reports which classified the volatile organic compounds as carcinogenic [4].

\section{Concentration of Pollutants at Varying Distances}

The results of the air quality measurement carried out at varying distances from the study areas are shown in tables 4 to 6 . These results were analyzed using regression analysis. The aim of the regression analysis is to determine if there is a relation between distance and concentration of pollutants recorded at the varying distances from the study areas. The correlation coefficient shows the strength of the relationship between dependent and independent variable [10]. 
Table 4: Concentration of pollutants at varying distances from $\mathrm{U}_{1}$

\begin{tabular}{|l|l|l|l|l|l|l|l|l|l|l|}
\hline \multirow{2}{*}{$\begin{array}{l}\text { Pollutants } \\
\mathrm{Mg} / \mathrm{m}^{3}\end{array}$} & \multicolumn{6}{|l|}{ Concentrations of Pollutants at Distance $(\mathrm{m})$} \\
\cline { 2 - 14 } & 20 & 40 & 60 & 80 & 100 & 120 & 140 & 160 & 180 & 200 \\
\hline $\mathrm{PM}_{1}$ & 0.02 & 0.03 & 0.02 & 0.01 & 0.010 & 0.06 & 0.08 & 0.04 & 0.06 & 0.01 \\
\hline $\mathrm{PM}_{2.5}$ & 0.01 & 0.04 & 0.10 & 0.15 & 0.06 & 0.02 & 0.24 & 0.09 & 0.36 & 0.45 \\
\hline $\mathrm{TSP}$ & 0.46 & 0.48 & 0.36 & 0.61 & 0.72 & 0.56 & 0.33 & 0.22 & 0.67 & 0.54 \\
\hline $\mathrm{NO}_{2}$ & 0.16 & 0.17 & 0.22 & 0.17 & 0.13 & 0.14 & 0.21 & 0.29 & 0.15 & 0.09 \\
\hline $\mathrm{SO}_{2}$ & 0.13 & 0.14 & 0.09 & 0.10 & 0.14 & 0.15 & 0.15 & 0.14 & 0.08 & 0.12 \\
\hline $\mathrm{VOCs}$ & 100.67 & 80.32 & 40.43 & 20.43 & 10.17 & 7.87 & 7.66 & 6.98 & 5.42 & 5.00 \\
\hline $\mathrm{H}$ & 0.03 & 0.03 & 0.02 & 0.06 & 0.07 & 0.03 & 0.06 & 0.04 & 0.04 & 0.01 \\
\hline $\mathrm{CO}$ & 3.44 & 2.00 & 2.89 & 4.78 & 1.23 & 3.90 & 1.22 & 1.00 & 2,89 & 0.99 \\
\hline $\mathrm{CH}_{4}$ & 4.21 & 3.26 & 2.99 & 2.00 & 1.94 & 1.92 & 1.87 & 1.00 & 0.99 & 0.78 \\
\hline
\end{tabular}

Table 5: Concentration of pollutants measured at varying distances $\left(\mathrm{U}_{2}\right)$

\begin{tabular}{|l|l|l|l|l|l|l|l|l|l|l|l|}
\hline \multirow{2}{*}{$\begin{array}{l}\text { Pollutants } \\
\mathrm{Mg} / \mathrm{m}^{3}\end{array}$} & \multicolumn{6}{l}{ Concentrations of Pollutants at Distance $(\mathrm{m})$} \\
\cline { 2 - 12 } & 20 & 40 & 60 & 80 & 100 & 120 & 140 & 160 & 180 & 200 \\
\hline $\mathrm{PM}_{1}$ & 0.01 & 0.01 & 0.02 & 0.02 & 0.01 & 0.01 & 0.01 & 0.03 & 0.02 & 0.02 \\
\hline $\mathrm{PM}_{2.5}$ & 0.07 & 0.09 & 0.07 & 0.10 & 0.06 & 0.07 & 0.12 & 0.02 & 0.11 & 0.02 \\
\hline $\mathrm{TSP}$ & 0.03 & 0.04 & 0.06 & 0.06 & 0.03 & 0.10 & 0.06 & 0.06 & 0.12 & 0.13 \\
\hline $\mathrm{NO}_{2}$ & 0.18 & 0.16 & 0.20 & 0.18 & 0.27 & 0.25 & 0.45 & 0.17 & 0.33 & 0.28 \\
\hline $\mathrm{SO}_{2}$ & 0.11 & 0.21 & 0.22 & 0.15 & 0.16 & 0.19 & 0.22 & 0.14 & 0.17 & 0.15 \\
\hline $\mathrm{VOCs}$ & 60.23 & 35.23 & 20.43 & 9.35 & 3.91 & 4.76 & 2.96 & 1.99 & 2.74 & 2.77 \\
\hline $\mathrm{H}_{2} \mathrm{~S}$ & 0.14 & 0.11 & 0.20 & 0.13 & 0.17 & 0.24 & 0.32 & 0.09 & 0.31 & 0.45 \\
\hline $\mathrm{CO}$ & 4.00 & 2.14 & 4.12 & 2.43 & 3.12 & 3.22 & 2.67 & 3.98 & 4.89 & 2.98 \\
\hline $\mathrm{CH}_{4}$ & 0.00 & 0.00 & 0.00 & 0.00 & 0.00 & 0.00 & 0.00 & 0.00 & 0.00 & 0.00 \\
\hline
\end{tabular}

Table 6: Concentration of pollutants measured at varying distances $\left(\mathrm{U}_{3}\right)$

\begin{tabular}{|l|l|l|l|l|l|l|l|l|l|l|}
\hline \multirow{2}{*}{$\begin{array}{l}\text { Pollutants } \\
\mathrm{Mg} / \mathrm{m}^{3}\end{array}$} & \multicolumn{6}{l|}{ Concentrations of Pollutants at Distance $(\mathrm{m})$} \\
\cline { 2 - 12 } & 20 & 40 & 60 & 80 & 100 & 120 & 140 & 160 & 180 & 200 \\
\hline $\mathrm{PM}_{1}$ & 0.02 & 0.04 & 0.03 & 0.06 & 0.07 & 0.09 & 0.06 & 0.12 & 0.10 & 0.09 \\
\hline $\mathrm{PM}_{2.5}$ & 0.10 & 0.11 & 0.10 & 0.09 & 0.11 & 0.09 & 0.10 & 0.07 & 0.19 & 0.05 \\
\hline $\mathrm{TSP}$ & 0.23 & 0.19 & 0.31 & 0.24 & 0.27 & 0.30 & 0.42 & 0.39 & 0.47 & 0.35 \\
\hline $\mathrm{NO}_{2}$ & 0.17 & 0.11 & 0.19 & 0.20 & 0.13 & 0.12 & 0.14 & 0.16 & 0.20 & 0.12 \\
\hline $\mathrm{SO}_{2}$ & 0.15 & 0.18 & 0.18 & 0.14 & 0.15 & 0.13 & 0.15 & 0.17 & 0.15 & 0.19 \\
\hline $\mathrm{VOCs}$ & 58.65 & 40.34 & 26.23 & 15.23 & 10.45 & 9.45 & 3.23 & 2.45 & 3.78 & 2.44 \\
\hline $\mathrm{H}_{2} \mathrm{~S}$ & 0.14 & 0.11 & 0.20 & 0.13 & 0.17 & 0.24 & 0.32 & 0.09 & 0.31 & 0.45 \\
\hline $\mathrm{CO}$ & 3.20 & 3.80 & 3.68 & 3.76 & 4.00 & 3.24 & 3.34 & 3.60 & 3.02 & 3.72 \\
\hline $\mathrm{CH}$ & 4.21 & 3.24 & 3.10 & 2.93 & 1.61 & 0.99 & 0.44 & 0.34 & 0.43 & 0.00 \\
\hline
\end{tabular}




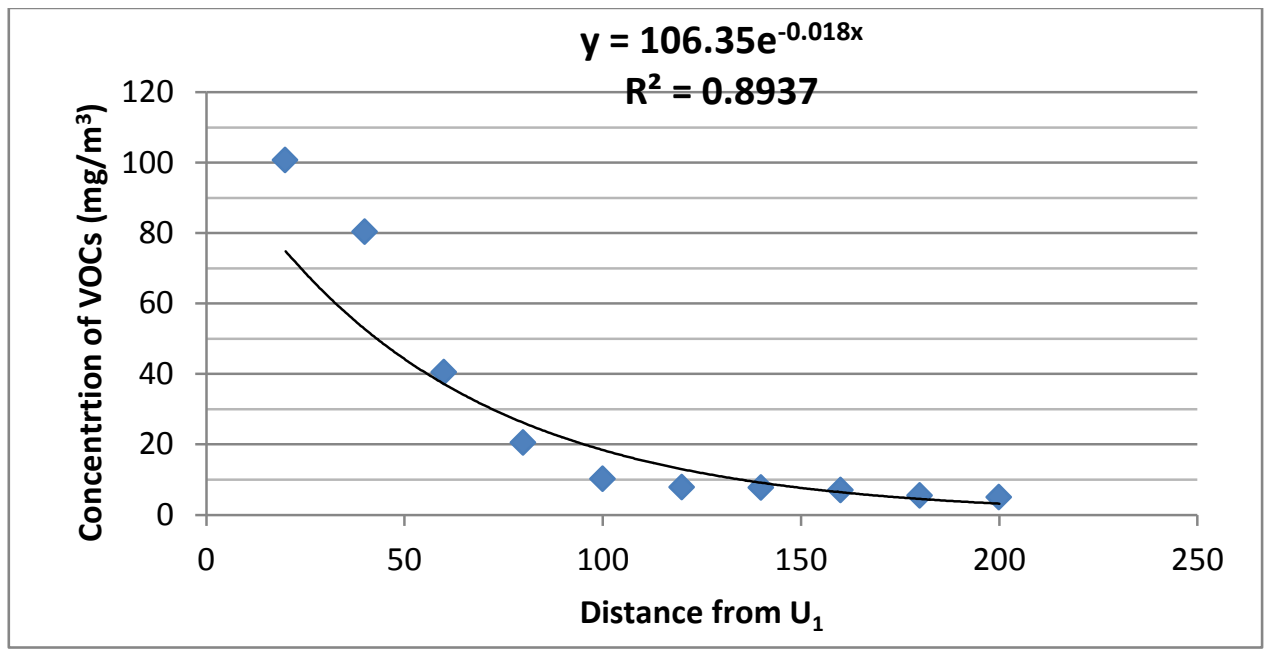

Figure 1: Concentration of $\mathrm{VOC}_{\mathrm{S}} \mathrm{VS}$ Distance from $\mathrm{U}_{1}$

There is an exponential relationship between the concentration of VOCs and distance from $\mathrm{U}_{1}$. The greater the distance from $\mathrm{U}_{1}$, the lesser the concentration of VOCs recorded, moving in exponential manner. Here the correlation coefficient $R$ is 0.945 while the coefficient of determination $\left(R^{2}\right)$ is 0.893 . As the correlation is close to 1 , it indicates that the trendline model which is $y=106.3 \mathrm{e}^{-0.01 x}$ is a good prediction model for future outcomes.

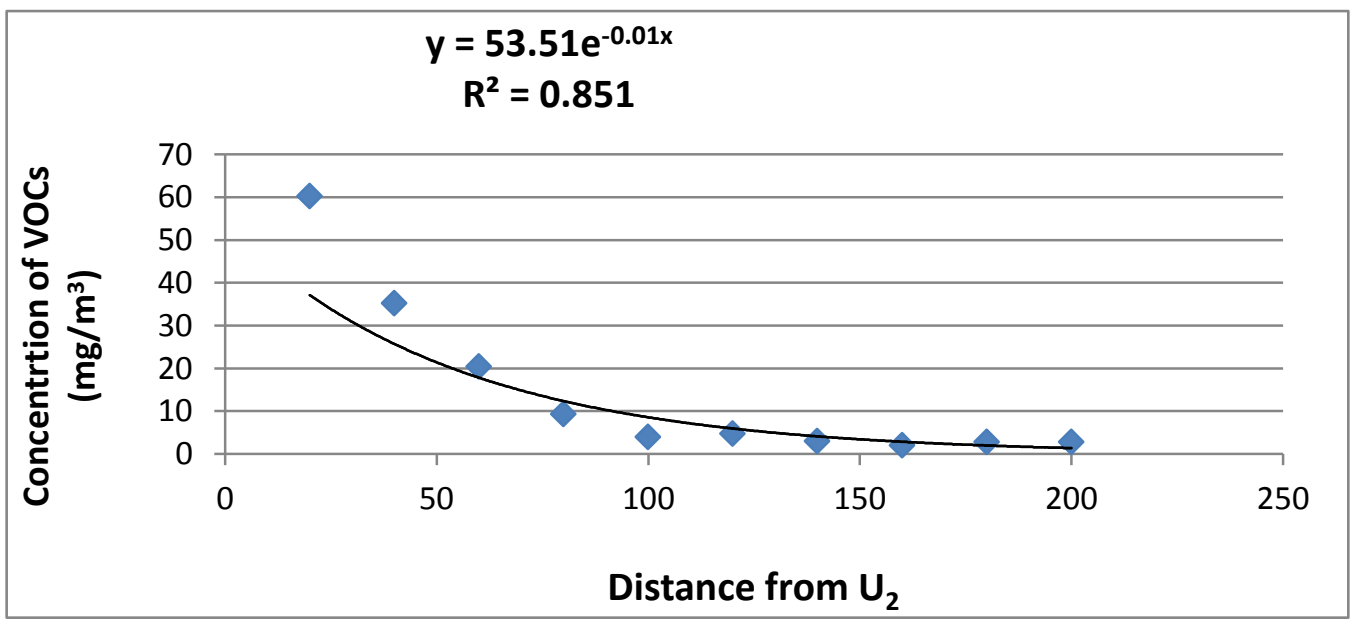

Figure 2: Concentration of VOCs VS Distance from $\mathrm{U}_{2}$

Figure 2 shows that there is a strong high negative exponential correlation between distance and concentration. Here it is seen that the greater the distance from $U_{2}$ the lesser the concentration of VOCs recorded. The value of the correlation coefficient $R=0.923$. The $R^{2}$ value is 0.851 while the trendline model is $y=53.51 \mathrm{e}$ $0.01 \mathrm{x}$ 


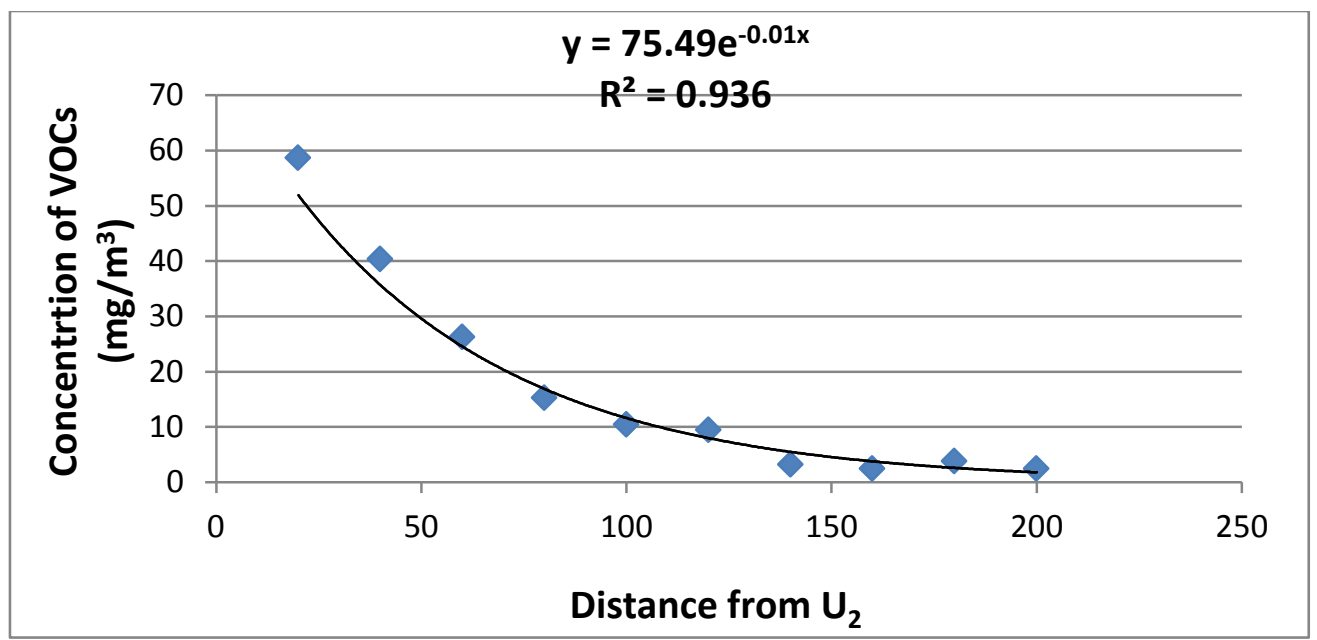

Figure 3: Concentration of VOCs VS Distance from $\mathrm{U}_{3}$

Figure 3 shows a strong negative exponential correlation between distance and concentration, here the greater the distance from $\mathrm{U}_{3}$, the lesser the concentration VOCs recorded. The correlation coefficient $(\mathrm{R})$ which stood at 0.967 confirms that there is a strong negative correlation between distance from $\mathrm{U}_{3}$ and the concentration of VOCs recorded. The formulated $\underset{0.01 x}{\exp x} \operatorname{contial}$ relationship obtained is $\mathrm{y}=75.49 \mathrm{e}$

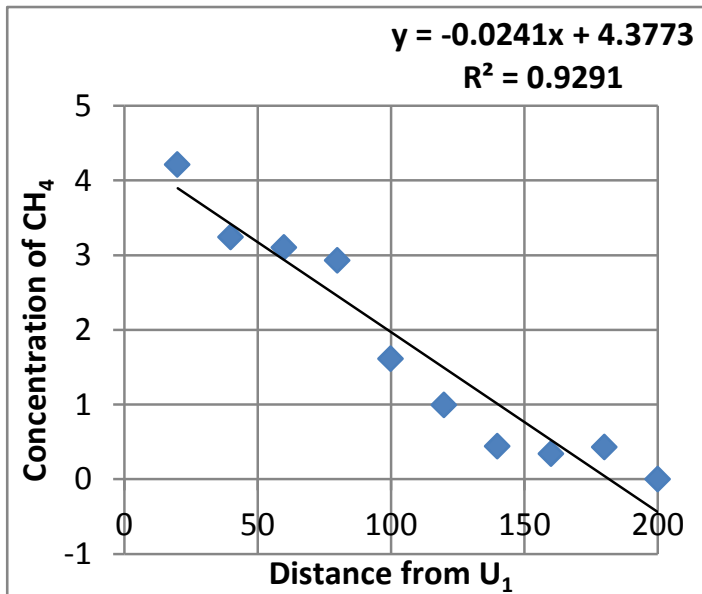

Figure 4: Conc. of $\mathrm{CH}_{4}$ vs Distance from $\mathrm{U}_{1}$

Figures 4 and 5 show a strong negative linear correlation between distance and concentration. The greater the distance from $U_{1}$ and $U_{3}$, the lesser the concentration of $\mathrm{CH}_{4}$ recorded in each case. The correlation coefficient $(\mathrm{R})$ which stood at 0.964 and 0.952 for $U_{1}$ and $U_{3}$ confirms that there is a strong negative correlation between distance from the $\mathrm{U}_{3}$ and the concentration of VOCs recorded. The formulated linear relation

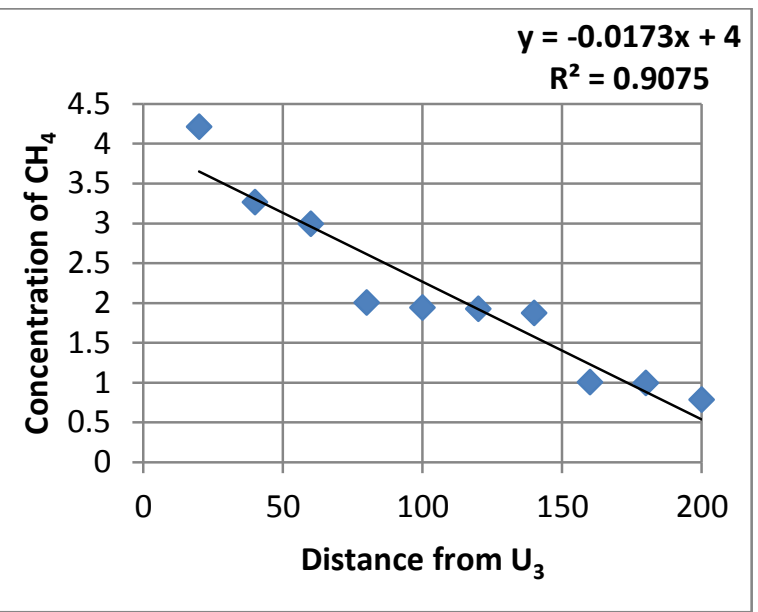

Figure 5: Conc. of $\mathrm{CH}_{4}$ vs Distance from $\mathrm{U}_{1}$

are $\mathrm{y}=-0.024 \mathrm{x}+4.377$ and $\mathrm{y}=0.017 \mathrm{x}+4$ for $\mathrm{U}_{1}$ and $U_{3}$, respectively. It has earlier been noted that $\mathrm{CH}_{4}$ concentration was high in $U_{1}$ and $U_{3}$ which comes from leakages from the storage tanks for cooking gas and evaporation during the dispensing of the gas to buyers. No trace of methane was recorded at station $\mathrm{U}_{2}$ because cooking gas was not sold in the station. 
Table 7: Summary of Observation from the Scatter Graphs

\begin{tabular}{|c|c|c|c|}
\hline Pollutants & $\mathrm{U}_{1}$ & $\mathrm{U}_{2}$ & $\mathrm{U}_{3}$ \\
\hline \multirow[t]{2}{*}{$\mathrm{PM}_{1}$} & $Y=0.000 x+0.06$ & $Y=5 E-0.5 X+0.01$ & $Y=0.000 x+0.017$ \\
\hline & $\begin{array}{l}\mathrm{R}=0.35 \text { Low positive } \\
\text { correlattion }\end{array}$ & $\begin{array}{l}\mathrm{R}=0.47 \quad \text { Some } \\
\text { correlation }\end{array}$ & $\begin{array}{l}\mathrm{R}=0.86 \quad \text { high } \\
\text { correlation }\end{array}$ \\
\hline \multirow[t]{2}{*}{$\mathrm{PM}_{2.5}$} & \multirow{2}{*}{$\begin{array}{l}Y=0.001 x-0.060 \\
r=0.78 \\
\text { High posive correlation }\end{array}$} & $Y=-0.000 x+0.089$ & \multirow{2}{*}{$\begin{array}{l}\mathrm{Y}=2 \mathrm{E}-0.5 \mathrm{x}+0.1 \\
\mathrm{R}=0.032 \text { no corrrelation }\end{array}$} \\
\hline & & $\begin{array}{l}\mathrm{R}=0.43 \text { Some } \\
\text { correlation }\end{array}$ & \\
\hline \multirow[t]{2}{*}{ TSP } & \multirow{2}{*}{$\begin{array}{l}Y=0.000 x+0.483 \\
R=0.0316 \\
\text { No corrrelation }\end{array}$} & $y-0.000 x+0.022$ & \multirow{2}{*}{$\begin{array}{l}Y=0.001 x+0.183 \\
R=0.81 \\
\text { High positive correlation }\end{array}$} \\
\hline & & $\begin{array}{l}\mathrm{r}=0.76 \quad \text { High } \\
\text { correlation }\end{array}$ & \\
\hline \multirow[t]{2}{*}{$\mathrm{NO}_{2}$} & \multirow{2}{*}{$\begin{array}{l}Y=-0.000 x+0.189 \\
R=0.11 \quad \text { Low negative } \\
\text { correlation }\end{array}$} & \multirow{2}{*}{$\begin{array}{l}Y=0.000 x+0.156 \\
R=0.55 \\
\text { Some positive correlation }\end{array}$} & \multirow{2}{*}{$\begin{array}{l}Y=5 E-0.5 x+0.159 \\
r=0.083 \text { No correlation }\end{array}$} \\
\hline & & & \\
\hline $\mathrm{SO}_{2}$ & $\begin{array}{l}Y=-3 E-0.5 x+0.127 \\
R=0.07 \\
\text { No correlation }\end{array}$ & $\begin{array}{l}Y=-0.000 x+0.205 \\
R=0.49 \\
\text { Some negative correlation }\end{array}$ & $\begin{array}{l}Y=3 E-0.5 x+0.155 \\
R=0.001 \mathrm{No} \\
\text { Correlation }\end{array}$ \\
\hline \multirow[t]{2}{*}{ VOCs } & $Y=106.3 e^{-0.01 x}$ & $Y=53.51 e^{-0.01 x}$ & $Y=75.49 e^{-0.01 x}$ \\
\hline & $\begin{array}{l}\mathrm{R}=0.945 \\
\text { High positive correlation }\end{array}$ & $\begin{array}{l}\mathrm{R}=0.922 \text { High } \\
\text { correlation }\end{array}$ & $\begin{array}{l}\mathrm{R}=0.967 \quad \text { High } \\
\text { correlation }\end{array}$ \\
\hline \multirow[t]{2}{*}{$\mathrm{H}_{2} \mathrm{~S}$} & $Y=1 E-0.5 x+0.448$ & $Y=0.001 x+0.073$ & $\mathrm{Y}=0.001 \mathrm{x}+0.075$ \\
\hline & $\begin{array}{l}\mathrm{R}=0.031 \\
\text { No correlation }\end{array}$ & $\begin{array}{l}\mathrm{R}=0.69 \quad \mathrm{High} \\
\text { correlation }\end{array}$ & $\begin{array}{l}\mathrm{R}=0.69 \quad \mathrm{High} \\
\text { correlation }\end{array}$ \\
\hline $\mathrm{CO}$ & $\begin{array}{l}Y=-0.002 x+2.575 \\
R=0.12 \\
\text { Low negative correlation }\end{array}$ & $\begin{array}{l}\mathrm{Y}=0.001 \mathrm{x}+3 \\
\mathrm{R}=0.69 \text { Some } \\
\text { correlation }\end{array}$ & $\begin{array}{l}Y=-0.001 x+3.642 \\
R=0.18 \text { No correlation }\end{array}$ \\
\hline $\mathrm{CH}_{4}$ & $\begin{array}{l}Y=-0.024 x+4.377 \\
R=0.964 \\
\text { High negative correltaion }\end{array}$ & & $\begin{array}{l}Y=0.017 x+4 \\
R=0.952 \quad \text { High } \\
\text { correlation }\end{array}$ \\
\hline
\end{tabular}

The results of the relationships are summarized in the table 7 . It is important to note that positive correlation means that the higher the distance from the study area the greater the concentration of pollutants recorded. Its implication is that the study area is not responsible for the presence of the pollutant in the atmosphere. Here some other sources may be responsibe for such pollutants. Negative correlation on the other hand implies that the greater the distance from the study areas the lesser the concentration of pollutants recorded. It can be concluded that negative correlation means that the study area is responsible for the presence of the pollutant in the ambient air. In situtations of no correlation, it means that there is a random distribution of pollutants in the ambient air and that the exact source of the pollutants cannot be determined. In table 7 it can be shown that only VOCs and $\mathrm{CH}_{4}$ are present in the atmosphere as a result of activities in the stations. This is because the level of VOCs and $\mathrm{CH}_{4}$ concentration were found to decrease in the ambient air as the distance from the stations increases. Hence, VOCs and $\mathrm{CH}_{4}$ concentrations hava a strong negative relationship with distance from the study areas. This is because the level of the pollutants concentration were found to decrease in the ambient air as the distance from the stations increases. Therefore, it can be infered that methane and volatile organic compounds are the primary pollutants to be considered in siting a 
filling station. A special interest is paid to VOCs due to reports from WHO labeling VOCs especially benzene as being a carcinogenic substance capable of causing cancer in human [4].

\section{Finding the Safe Distance to Site a Filling Station}

From the result of the measurements carried out at the controls, it was discovered that VOCs and $\mathrm{CH}_{4}$ are the primary pollutants which are found in the air as a result of the activities in the filling stations. Therefore in siting a filling station, it is important that a distance is maintained between the stations and residential areas. Using the result of the measurements carried at the control and comparing it with the FEPA air quality standards, the safe distance to site a filling station can be established. The safe distance is that point which the effect of the pollutants from the stations has been reduced to tolerable minimum. At this point, the value of pollutants recorded must be within the FEPA acceptable limits of exposure. In finding the safe distance, methane was not considered because there is no FEPA limits of exposure for methane but it is important that the station is sited at a distance where the concentration of methane is very low. To make this comaprison, figure 6 was employed.

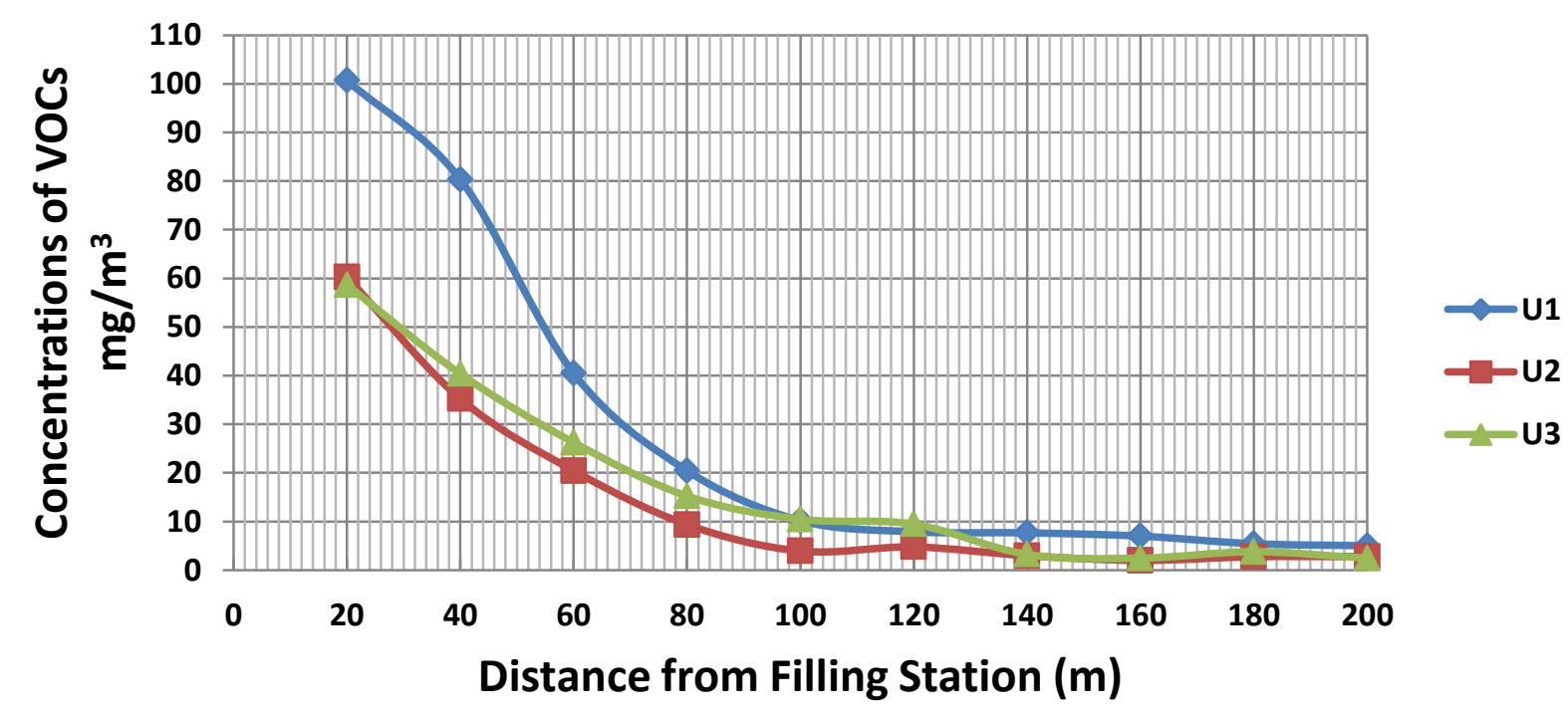

Figure 6: Concentration of VOCs at varying distance from $U_{1}, U_{2}$ and $U_{3}$

Figure 6 shows that the distances away from the filling stations of $U_{1}, U_{2}$ and $U_{3}$ for the concentration of VOCs at FEPA's acceptable limit (i.e. $40 \mathrm{mg} / \mathrm{m}^{3}$ ) stood at $60 \mathrm{~m}, 35 \mathrm{~m}$ and $40 \mathrm{~m}$, respectively. Considering errors of measurement and the fact that their may be some filling stations that might emit higher concentrations, a factor of safety of $20 \mathrm{~m}$ was added to the filling station $\left(U_{1}\right)$ that emitted the highest VOCs from the case studies. Hence, it is suggested that the safe distance to site a filling station is $80 \mathrm{~m}$ away from residential areas. After this distance all the emitted volatile organic compounds must have been absorbed into the higher atmosphere

\section{CONCLUSION}

This study of gas emissions from filling station and their effect on the air quality showed that filling station located in our cities have the tendency to constitute health hazard risk owing to its contribution to air pollution. Different pollutants were recorded at the study areas namely; particulate matters, nitrogen dioxide, sulphur dioxide, volatile organic compounds, hydrogen sulphide, carbon monoxide and methane. Comparing the average concentration of pollutants at the study areas to the FEPA air quality guidelines showed that many of the 
pollutants concentration exceeded the FEPA limits of exposure. The data obtained from the controls were evaluated using regression analysis and the results showed that the major pollutant to be considered when citing filling stations is the volatile organic compounds and methane. From the regression analysis, the safe distance to site filling station is a distance of about $80 \mathrm{~m}$. At this distance, volatile organic compounds emitted from the station must have been evaporated into the higher atmosphere thereby eliminating the possibility of harm to people living in the residential areas. From the results of the study, it can be concluded that the air quality in our towns and villages is negatively affected due to emissions of pollutants from petrol stations into the ambient air. Therefore urgent actions should be taken to arrest this ugly trend.

\section{REFERENCES}

Joseph, P and Riva, J. R., 2010.The history of the words petroleum industry.1.6-7. Newyork publisher.

Timothy, P. M., 2006. Health and environment effect of air pollution. USEPA publications, 23-25.

Isabel, M.C., Graciela, A and Monica, R.C., 2010.Evaluating emission from gas stations. Journal of environmental management. 6.42-50.
Sergio, M., 2008.The impact of BTEX emission from gas stations into the atmosphere. Air pollution Research Journal 23.12-14.

Kagawa.J., 1985.Evaluation of biological significance of nitrogen exposure. Pharmacol. 4. 199.

Ghio, A. J and Huang, Y., 2004. Exposure to concentrated ambient particles.Journal of atmospheric environment. 41.14561472.

Chauban, A. J., Krishna, M. T and Frew, A.J., 1998.Exposure to nitrogen dioxide and respiratory disease risk.Environmental Health journal.13,73.

Wikipedia.,

2014.

Umuahia. www.wikipedia.org/umuahia. June 2014.

FEPA., 1996. Guidelines and standards for environmental protection and control. FEPA publications 12.32-33.

Egbe, E., Odili, G.A andUgbebor, O.O., 2000. Further mathematics. Africana First Publishers Limited. 